Bull. Mater. Sci., Vol. 16, No. 6, December 1993, pp. 433-451. (C) Printed in India.

\title{
Some recent innovations in the Kroll process of titanium sponge production
}

\author{
R B SUBRAMANYAM \\ Defence Metallurgical Research Laboratory, Hyderabad 500258 , India
}

\begin{abstract}
Titanium and its alloys have emerged as cost-effective structural materials in many spheres of chemical and engineering industries including aerospace and power generation. Titanium in its pure form is invariably prepared starting from pure titanium tetrachloride. Titanium tetrachloride obtained by chlorination of the oxide mineral is purified and reduced with either liquid magnesium or sodium or electrolysed to obtain titanium in sponge form. The metal extraction processes are so complex that large scale production technology is limited so far only to a few countries in the world viz. the USA, Japan, CIS. UK and China. India is attempting to enter this arena shortly with a $1000 \mathrm{TPY}$ commercial plant based entirely on home-grown technology.

Among the extraction methods, the magnesium reduction of titanium tetrachloride, patented by W J Kroll in 1940, has received wider attention because of the inherent and relative merits of the process and its viability for economic production on an industrial scale. The original Kroll process, however, has undergone several modifications in the past few decades. The recent technological breakthroughs in the Kroll process as well as in the magnesium recycling technology has resulted in a significant reduction in the production cost of the metal. The paper describes these important innovations and also the efforts that are being put in for the establishment of a commercial plant for metal production in India based on indigenously developed technology.
\end{abstract}

Keywords. Titanium extraction; Kroll Process: process innovations and breakthroughs; titanium production in India; magnesium recycling; multipolar cell.

\section{Introduction}

Though the metal titanium entered industrial use as a material for high-speed military aircraft in the early fifties in the United States mainly on account of its superior specific strength, it has later found diversified engineering applications on recognition of its several other extraordinary properties. Starting with a limited use in the Boeing 707 in the sixties, titanium and its alloys now have a share of more than ten weight per cent in the new Boeing 777 which is expected to fly by 1995. In parallel there has been a matching growth in non-aerospace applications of the metal as well. While production in the fifties was a mere 50 tonnes, currently the installed capacity of titanium sponge production stands at around 120,000 tonnes per year. This mega growth is obviously because of the realization of the unique attributes of the metal such as its high strength to weight ratio, amenability to property tailoring with alloying additions, superior corrosion/erosion resistance, and so on. The compatibility of titanium with carbon-fibre-reinforced polymer composites (CFRP), because of the relatively lower galvanic potential between carbon and titanium compared to carbon and aluminium, makes the metal more suitable for use in combination with CFRPs, typically in modern airplane structural components.

Industrial production of sponge titanium is at present limited to only five countries, namely the USA, the erstwhile USSR, Japan, the UK and China. India will soon be 
joining this select group of countries with the establishment of its first commercial plant of 1000 TPY capacity at Palayakayal mear Tuticorin in Tamil Nadu.

There are three metal production technologies established for commercial production, viz. the Kroll's magnesium reduction of titanium tetrachloride, the Hunter's sodium reduction of titanium tetrachloride, and the fused salt electrolysis of the tetrachloride. While the Kroll process accounts for over $80 \%$ of the global production, the fused salt electrolysis is yet to prove its industrial viability. Since the beginning of commercial production in late fifties, the demand for titanium sponge has been erratic mainly due to the vicissitudes of the aerospace industry. However, the oil crisis of the mid seventies led to a substantial increase in the demand for titanium for fuel-efficient aircraft engines on the one hand and for building large-scale desalination plants in the oil-rich Gulf countries on the other. Consequently there was a rapid expansion of capacity for titanium sponge all over the world and especially in Japan during this period leading to the present world capacity of 120,000 tonnes per year (table 1).

Figure 1 shows the average year-end titanium sponge price profile from the beginning of the industry till recently. There has been a drastic fall in the sponge price till the seventies which is mainly because of the continuously increased production rates. The stead increase in the price during the period 1974 to late 1979 was due to high demand for titanium sponge from the aerospace industry in the USA and from the chemical industry, desalination plants and power plants in Japan and the Gulf countries. In addition there was a suspension of Soviet exports to the West in the year 1978 leading to a wide gap in the supply and demand position which was subsequently bridged by capacity expansion as mentioned above. The current international price for sponge ranges from US\$ 8 to US\$10 per $\mathrm{kg}$.

Table 1. World titanium sponge production (tonnes/year).

\begin{tabular}{lccr}
\hline Country & Na-reduction & Mg-reduction & Gross \\
\hline USSR & - & 45,000 & 45,000 \\
Japan & 2400 & 32,000 & 34,400 \\
USA & 8600 & 23,600 & 32,200 \\
UK & 5000 & - & 5000 \\
China & - & 3000 & 3000 \\
Total & 16,000 & 103,600 & 119,600 \\
$\%$ & $13 \cdot 4$ & 86.6 & 100 \\
\hline
\end{tabular}

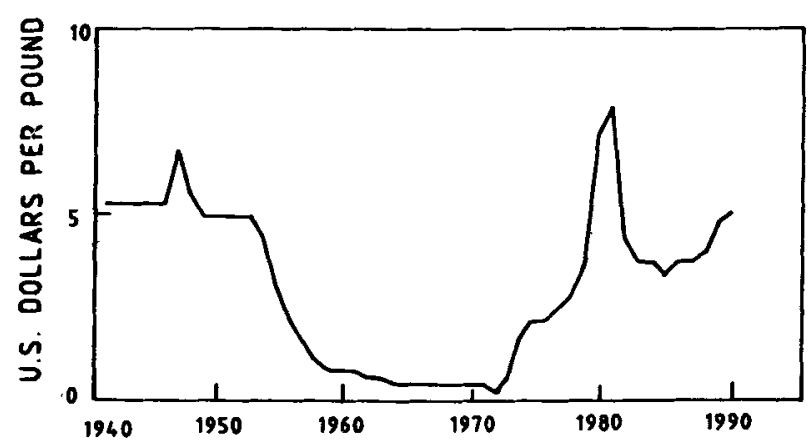

Figure 1. Average year-end titanium sponge price. 
The increase in the use of titanium for diverse applications during recent years can be attributed to the steady decline in the price of sponge and finished products achieved as a result of unabated $R \& D$ particularly in the following areas:

(i) Kroll process of sponge production,

(ii) melting and processing of sponge with specific reference to scrap utilization, and

(iii) near-net-shape technologies such as Skull melting and casting, isothermal forging, super plastic forming, etc.

Undoubtedly the breakthroughs achieved in the Kroll process technology have contributed to a great extent to the downward price trend during the eighties. This paper reviews some of these innovations and also discusses India's own efforts in developing state-of-the-art technologies for titanium and magnesium production.

\section{The Kroll process and the newer innovations}

Despite its early discovery at the end of the eighteenth century, it took more than 100 years to prepare the metal titanium in a relatively pure form and another 40 years to develop a process that has commercial production capability. W J Kroll was the first to attempt reduction of pure titanium tetrachloride ( $\mathrm{TiCl}_{4}$ ) with liquid magnesium in a sealed reactor under an inert gas atmosphere in the year 1945 (Kroll 1940). Though the processing steps evolved by Kroll have remained essentially unchanged over the years, there have been several advancements in various aspects of the production technology as currently practised in large commercial plants.

In industrial practice the oxide ores of titanium are subjected to high-temperature chlorination in fluidized bed reactors and the tetrachloride thus obtained is purified in distillation columns. The reaction between pure titanium tetrachloride and liquid magnesium is carried out in sealed stainless steel reactors under inert gas cover. Though there is a proven existence of intermediate species such as $\mathrm{TiCl}_{2}$ and $\mathrm{TiCl}_{3}$, the reaction

$$
\mathrm{TiCl}_{4}+2 \mathrm{Mg}=\mathrm{Ti}+2 \mathrm{MgCl}_{2}, \mathrm{H}_{1100 \mathrm{~K}}=102 \mathrm{kcal} / \mathrm{mole},
$$

represents the overall reduction. While the lower limit of reduction temperature is governed by the melting point of magnesium chloride $\left(712^{\circ} \mathrm{C}\right)$, the upper limit is set at $1000^{\circ} \mathrm{C}$ to minimize contamination by iron, increase the useful life of the reactor, and avoid the eutectic reaction between titanium and iron. Usually the reduction temperature ranges between 850 and $900^{\circ} \mathrm{C}$. During the reduction process, in order to accommodate the increase in the volume of the reaction mass, the by-product magnesium chloride is discharged in molten form from time to time. The tapped magnesium chloride is sent to electrolytic cells for the production of magnesium metal and chlorine gas for captive reuse. At the end of reduction, the reaction mass is subjected to vacuum distillation (at about $1000^{\circ} \mathrm{C}$ ) to distil out the entrapped magnesium and magnesium chloride from titanium sponge. Leaching of the reduced mass (after crushing) in hydrochloric acid followed by drying is also practised alternatively for purification of the sponge.

Thus, the major processing steps involved in the Kroll production of titanium sponge include the following:

production of titanium tetrachloride by chlorination of beneficiated oxide ores $/ \mathrm{TiO}_{2}$-rich slags 
reduction of titanium tetrachloride by magnesium followed by vacuum distillation fused salt electrolysis of magnesium chloride to recycle magnesium and chlorine.

Over the past several years there have been a number of innovations and technological breakthroughs in the above steps that have revolutionized production technology resulting in the production of high-quality sponge on a massive scale at a substantially lower cost. Among them the most important advancements are: (i) fluidized bed chlorination, (ii) combined reduction and vacuum distillation, (iii) increased batch size, (iv) improved operational performance and increased productivity with the use of advanced instrumentation and computerization, (v) sophisticated sponge handling and quality evaluation techniques, and (vi) development of multipolar cells for magnesium electrowinning.

\subsection{Fluidized bed chlorination}

Titanium tetrachloride is produced by the chlorination of oxide concentrates in the presence of carbon. The ground ore concentrate used to be briquetted along with coke and the chlorination carried out at a temperature of $900-1000^{\circ} \mathrm{C}$. The erstwhile conventional static bed chlorination was not only limiting the production rates but also leading to increased consumption of chlorine.

Advent of fluidized bed chlorination technology gave a gigantic impetus to the industrial production of titanium tetrachloride. In fluidized bed processing, the chlorine gas itself is used as the fluidizing medium and the initial heat requirements are mostly met by combusting a part of the coke with oxygen introduced along with the chlorine gas. The advantages offered by this technology include excellent gas-solid contact resulting in efficient heat transfer and increased reaction rates, enhanced productivity, and increased materials utilization. Optimal control of reaction temperature has also been possible by employing computer-based process control systems. An increase in the production rate of nearly $50 \%$ is reported (Noda 1988) from Japan with the employment of fluidized bed reactor (FBR) technology. Figure 2

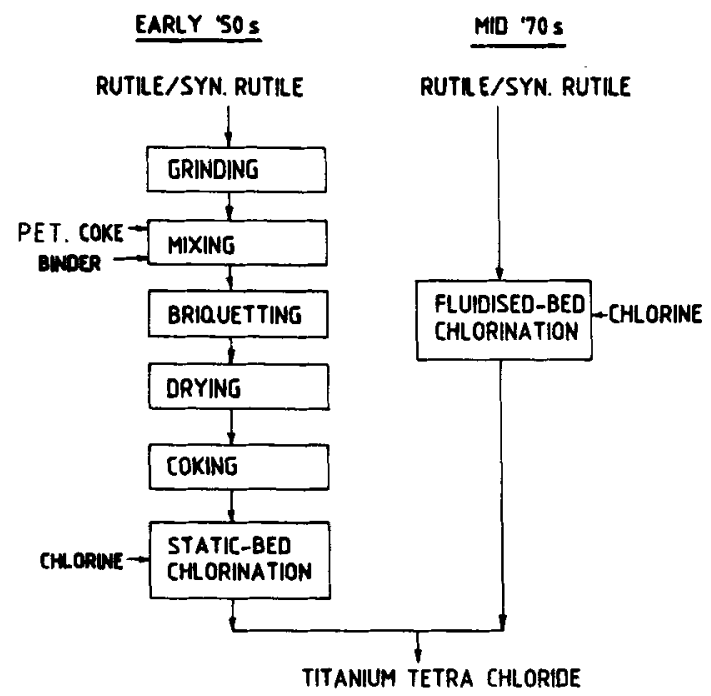

Figure 2. Production of titanium tetrachloride. 
Table 2. Improvements in chloride production technology.

\begin{tabular}{lcc}
\hline & $\begin{array}{c}\text { Static } \\
\text { bed }\end{array}$ & $\begin{array}{c}\text { Fluidized } \\
\text { bed }\end{array}$ \\
\hline $\begin{array}{c}\text { Coke consumption } \\
\left(\mathrm{kg} / \mathrm{t} \text { of } \mathrm{TiCl}_{4}\right)\end{array}$ & 180 & 90 \\
$\begin{array}{c}\text { Chlorine consumption } \\
\left(\mathrm{kg} / \mathrm{t} \text { of } \mathrm{TiCl}_{4}\right)\end{array}$ & 880 & 800 \\
$\begin{array}{c}\text { Energy consumption } \\
\left(\times 10^{3} \mathrm{kcal} / \mathrm{t} \text { of } \mathrm{TiCl}_{4}\right)\end{array}$ & 1560 & 500 \\
$\begin{array}{l}\text { Titanium yield } \\
(\%)\end{array}$ & 95 & 98 \\
\hline
\end{tabular}

compares the processing steps involved in static bed chlorination with fluidized bed chlorination and table 2 shows some of the improvements obtained in the operational results with the implementation of FBR technology.

\subsection{Increased batch size}

As the Kroll process is basically a batch process, enlargement of batch size has been engaging the attention of the sponge producing community since the early sixties with a view to bringing down the production cost of metal by reduction in the capital costs and labour for operations. Constraints like distortion of bigger reactors, proper control of the process parameters, and complexities in the design of equipment for the handling and processing of the distilled sponge cake limited the batch size to 1-2 tonnes till the seventies. Further, the fear of overheating during 'reduction' and lack of adequate heat penetration during 'distillation' has restricted vessel diameters and therefore batch capacities.

However, with accumulated production experience and judicious design and selection of equipment it became easier to solve the engineering problems associated with enlargement of batch size. Currently plants in the USA, the former USSR and Japan have established facilities to produce sponge in $4,5,7$ and even 10 tonne batches (Toshio 1985).

With increased batch size, the levels of impurities such as iron, carbon, oxygen, nitrogen, etc. also came down quite substantially, with consequential increase in the percentage of saleable premium quality sponge.

\subsection{Combined process technology}

Titanium sponge production technology took a new dimension with the advent of the combined process in which the vacuum separation of reaction mass (as obtained on reduction of titanium tetrachloride) is carried out in situ in the same unit and also immediately after the reduction operation, without involving cooling of the reaction mass from reduction temperature to ambient temperature and reheating to high temperature after transferring to vacuum separation assembly as is done in the conventional process. The idea of combining the reduction and vacuum distillation 
Table 3. Power conservation in combined process technology (2T-Ti batch, China).

\begin{tabular}{lcccc}
\hline & & \multicolumn{3}{c}{ Combined process } \\
\cline { 3 - 5 } Item & $\begin{array}{c}\text { Conventional } \\
\text { process } \\
(\mathbf{k W h})\end{array}$ & $\begin{array}{c}\text { Power } \\
\text { consumption } \\
(\mathbf{k W h})\end{array}$ & $\begin{array}{c}\text { Power } \\
\text { conservation } \\
(\mathbf{k W h})\end{array}$ & $\begin{array}{c}\text { Power } \\
\text { conservation } \\
\%\end{array}$ \\
\hline Titanium & 10,286 & 5836 & 4450 & $43 \cdot 3$ \\
Magnesium & 27,800 & 20,932 & 6869 & $24 \cdot 7$ \\
Total & 38,086 & 26,768 & 11,319 & 30 \\
\hline
\end{tabular}

processes dates back to the early fifties. In 1956 El. du Pont Nemours \& Co. obtained a patent for this process (Winter Jr 1956). However, there were several engineering difficulties that had to be overcome for the industrial implementation of the process. These included isolation of the vacuum system from the reactor during reduction, thermal expansion of the interconnecting pipe, and prevention of condensation of vapours within the connecting pipe. The technological efforts that had been put in over a period of two decades finally led to the successful implementation of this process in the USSR initially, followed by Japan.

The advantages offered by the combined process include increased equipment productivity, decreased power consumption and labour requirement, and improved quality of the product. Table 3 shows the reports from a Chinese plant on energy conservation with the use of the combined process on $2 \mathrm{~T}$ scale (Wang and $\mathrm{Ma}$ 1989). Improved material handling techniques such as transfer of by-product molten magnesium chloride from the Kroll reactor directly to the electrolytic cell and charging of molten magnesium from the cell directly into the Kroll reactor have not only led to further conservation of energy but also to improved overall magnesium recovery and substantial saving in labour costs.

There have also been further improvements in the quality of sponge especially with respect to interstitial impurities such as nitrogen and oxygen due to complete elimination of exposure of the batch to atmosphere after reduction and prior to vacuum distillation. Thus it has now become possible to produce premium quality sponge to meet the stringent quality requirements of the aerospace industry much more economically than ever before.

\subsection{Sponge handling and evaluation techniques}

The sponge obtained on reduction and vacuum distillation is not uniform in quality since it is the product of a batch process extending over several days in operation. While the outer and bottom layers of the sponge cake are bound to contain higher levels of iron and carbon, the top layers contain higher levels of magnesium and chlorine in comparison to the core of the sponge cake which is generally of very high purity. The factors that affect the quality of sponge have been extensively studied (Aleksandrovskii et al 1979; Sandler and Zakhenvich 1980). Over the years a wide variety of equipment have been designed and employed for efficient processing of the sponge cake, especially to handle the larger cakes. Also, intensive classification and 
sorting-out procedures have been evolved for isolating the high-purity sponge. In addition, there have been improvements in sampling and analytical techniques. Thermoelectric and photometric methods also are reported to have been evolved recently for fully automated classification of sponge (Kulkov et al 1992).

Figure 3 shows typical grading of sponge cake fractions. Using a high-capacity hydraulic guillotine press, the cake is segmented to six fractions as shown which are individually crushed and analysed to enable blending of lots to meet customer specification. Before commencement of crushing, the outer surface of the cake is thoroughly cleaned with pneumatic chippers to eliminate all external contamination. Random samples are then taken from the side surface and analysed for nitrogen. If the nitrogen value exceeds $1 \%$, the entire cake is rejected. After this primary check, the cake is sliced all around using the guillotine press up to a depth of about $50 \mathrm{~mm}$ thickness and once again random samples are analysed for hardness, oxygen and nitrogen whose values should not exceed $120 \mathrm{BHN}, 0.15 \%$ and $0.02 \%$ respectively. After this the core is split into two parts $\left(A_{1}\right.$ and $\left.A_{2}\right)$ as shown in figure 3 and the individual fractions are separately crushed to size through a series of jaw crushers and roll crushers and passed through a magnetic separator before final blending. Blends of $5 \mathrm{~T}$ capacity are standard industrial practice. The finished material is packed in $250 \mathrm{~kg}$ air-tight drums under a protective cover of argon. Even at this stage, out of 20 drums two randomly picked drums are subjected to $100 \%$ visual inspection and coloured particles, if any, are hand-picked and analysed for nitrogen. If the nitrogen content is above $0.1 \%$, the entire lot is rejected. With the above quality

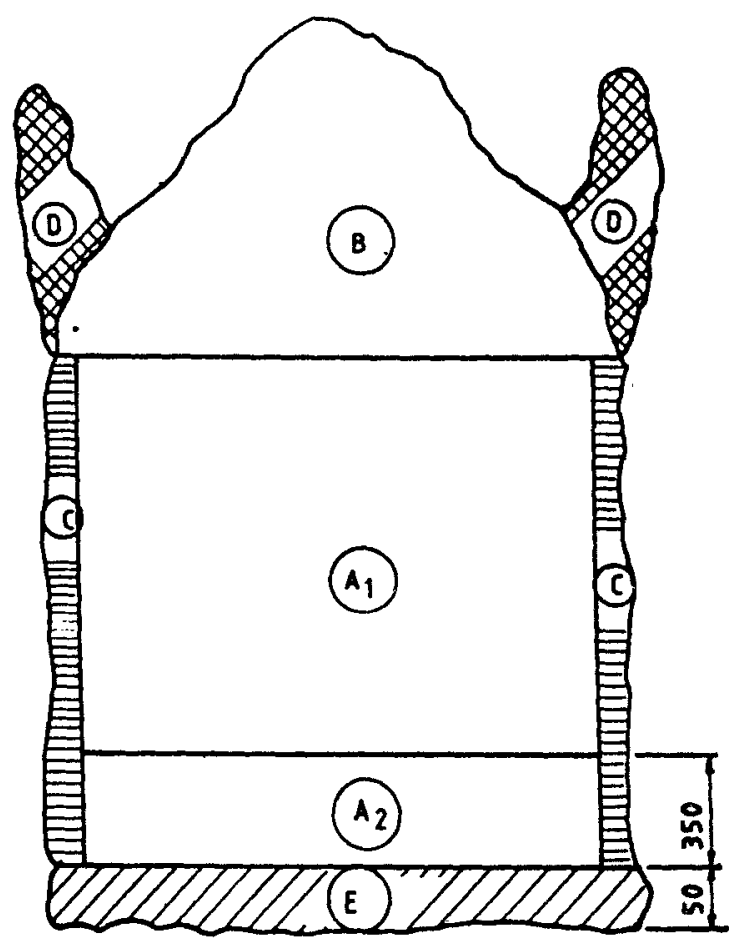

Figure 3. Typical grades of titanium sponge cake. $A_{1}, A_{2}$-high-purity grades; B, C, D - blendable grade; E - off-grade. 
assurance programme, the customer is now assured of a guaranteed product leading to negligible rejections on subsequent processing of sponge.

\subsection{Development of energy-efficient cells}

The economics of titanium production strongly depends on the cost of reprocessing of the by-product magnesium chloride to magnesium metal since $70-80 \%$ of the total energy consumed for titanium sponge production is in the magnesium chloride electrolysis. While the theoretical energy requirement for electrolytic production of magnesium from anhydrous magnesium chloride is $6.8 \mathrm{kWh} / \mathrm{kg}$, an actual power consumption as high as $50 \mathrm{kWh} / \mathrm{kg}$ had been recorded by Shawinigan Electro Metals Company, Canada, in 1918 (Peterson 1990). Intensive R \& D efforts over the years in the areas of cell feed preparation, cell design and cell operating parameters such as bath composition, operating temperature, etc. have borne fruit and the energy consumption in magnesium cells has gradually been reduced to about $10 \mathrm{kWh} / \mathrm{kg}$ of metal in the modern multipolar cells using molten magnesium chloride as cell feed material (Sivilotti 1984; Cameron et al 1987).

Despite intensive R \& D efforts over several years only the following four basic type of cells are currently in operation on an industrial scale: (i) the IG cell, (ii) the Dow cell, (iii) the diaphragmless cell, and (iv) the multipolar cell.

The current IG cell based on the original IG Ferben design of the twenties is an oblong chamber about $\mathbf{1 0}$ feet long internally lined with refractories as shown in figure 4. In this chamber graphite anodes are positioned between steel cathodes with anodes and cathodes senarated by refractory diaphragms to isolate the chlorine generated during the process from magnesium with a view to preventing recombination.
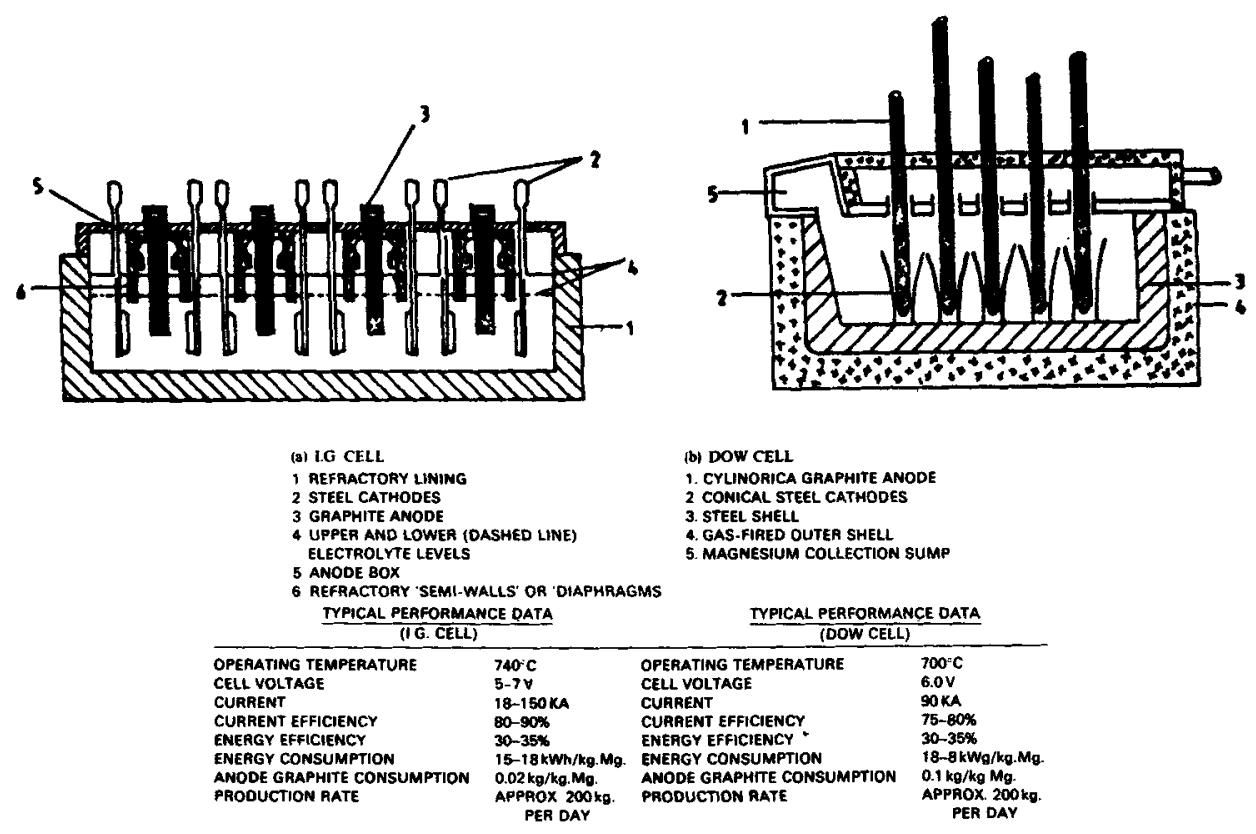

Figure 4. Schematic diagrams of (a) I G cell and (b) Dow cell. 
The IG cells modified from time to time are currently used by Norsk Hydro, Norway, and Amax Speciality Metals in the USA for large-scale commercial production of magnesium.

The Dow cell (figure 4) consists of a steel vessel externally heated by a gas-fired furnace. Conical steel cathodes are welded directly to the steel vessel while graphite anodes enter the cell via the refractory cover. This cell has been designed by Dow to accept hydrous feed with a composition of $\mathrm{MgCl}_{2} \cdot 1 \cdot 7 \mathrm{H}_{2} \mathrm{O}$ as a result of which there is heavy anode wear and frequent replacement of anodes. The cell operates on a high-conductivity, low-density electrolyte comprising a mixture of lithium chloride and magnesium chloride. Currently Dow is the only company producing magnesium from solid hydrous magnesium chloride feed.

The diaphragmless cell, the development of which took place in parallel in Canada by Alcan and in the erstwhile Soviet Union, is -considered the most advanced of monopolar cells. The absence of a diaphragm separating the cathode and anode resulted in a larger working volume and reduced the interpolar gap leading to significantly higher metal output for a given cell area. These cells utilize the gas lift action of chlorine for effective electrolyte circulation and separation of metal from the electrolyte in the metal collecting chamber without recombination. The concept of modularity in cell design also became an accepted practice in such diaphragmless cells. The tapered anode $100 \mathrm{kA}$ modular cell developed by Alcan Company, Canada, jointly with Osaka Titanium Company, Japan, was successfully operated by the Osaka Titanium Company for recycling their by-product magnesium chloride till very recently (Noda 1988).

The most significant development in the magnesium cell technology till date is undoubtedly the introduction of the multipolar cell. If an electrically conductive plate is inserted between the anode and the cathode of a conventional electrolytic cell, the side facing the anode becomes cathodic and the opposite side facing the cathode becomes anodic when DC current passes through the cell. The intermediate plate thus functions as a bipolar electrode and the productivity of the cell gets nearly doubled. By introducing several such bipolar electrodes between the main anode and the cathode and by repeating this arrangement in a mirror image fashion on the other side of the main anode, the productivity of the cell can be increased several fold. While the concept and the merits of the multipolar cell have been well known for several decades, its implementation particularly in fused salt electrolytic cells was a challenging task mainly due to (a) the complexity in the design of the bipolar electrode, and (b) the difficulty in avoiding the by-pass current that leads to a low current efficiency.

Alcan, Canada, in association with Osaka Titanium Company (Sivilotti 1985, 1990) and Ishizuka Research Institute, Japan, (Ishizuka 1987) have been remarkably successful in overcoming the above problems and commercial-sized cells based on their designs are now being successfully operated by Osaka Titanium Company and Showa Titanium Company in Japan. These cells are somewhat similar in design and figure 5 shows the type of cell in operation at the Showa Titanium Company.

In table 4, improvements in the magnesium cell technology achieved over the years are chronologically brought out and it needs to be once again emphasized that the dramatic reduction in respect of the specific energy consumption of magnesium production that has been achieved in multipolar cell has directly led to a significant reduction in the cost of production of titanium. 


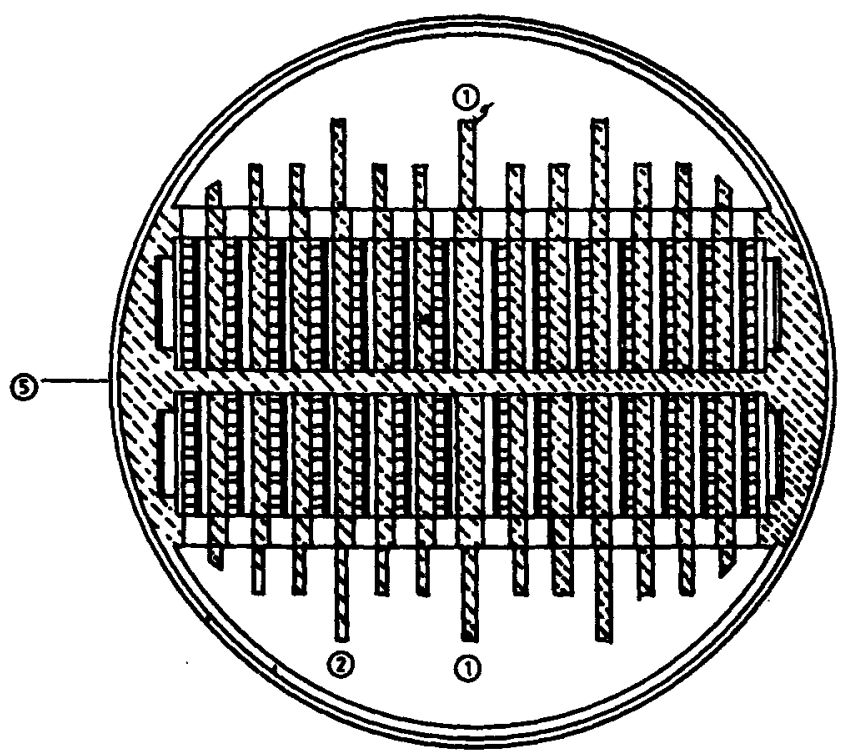

(1) CENTRAL GRAPHITE ANODES (2 Nos)

(4) REFRACTORY LINING

(2) STEEL/GRAPHITE BIPOLE ELECTRODES (6 Nos PER MODULE)

(5) STEEL SHELL

(3) STEEL CATHODES (4 NOS)

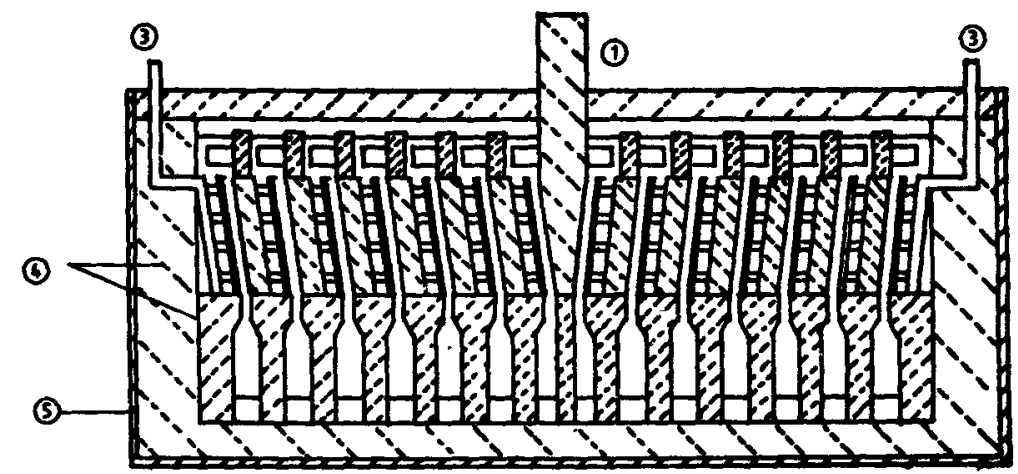

TYPICAL PERFORMANCE DATA

\begin{tabular}{ll}
\hline OPERATING TEMPERATURE & $670^{\circ} \mathrm{C}$ \\
CURRENT & $80 \mathrm{KA}$ \\
CURRENT EFFICIENCY & $76-80 \%$ \\
CURRENT DENSITY & $0.56 \mathrm{amp} / \mathrm{cm}^{2}$ \\
ENERGY CONSUMPTION & $10-11 \mathrm{kWh} / \mathrm{kg} . D C$ \\
PRODUCTION RATE & $3,000 \mathrm{~kg} / \mathrm{DAY}$ \\
\hline
\end{tabular}

Figure 5. Ishizuka multipolar cell (four modules).

\subsection{Summary of Kroll process innovations}

Some of the major technological breakthroughs and process improvements that have been achieved in respect of titanium sponge production by the Kroll process have been described above. As a result of these improvements the cost of production of titanium sponge has been significantly brought down by most of the leading sponge producers. In table 5 (Noda 1988) the operational results achieved by Osaka Titanium 
Table 4. Magnesium technology development.

\begin{tabular}{lccr}
\hline Cell design & Year & $\begin{array}{c}\text { Cell } \\
\text { capacity } \\
(\mathbf{k A})\end{array}$ & $\begin{array}{r}\text { Power } \\
\text { consumption } \\
\text { (kWh/kg) }\end{array}$ \\
\hline IG cell & 1930 & $60-120$ & $16-18$ \\
Dow cell & 1945 & - & $16-18$ \\
Alcan (monopolar) & 1961 & 100 & 18 \\
Dow cell modified & 1978 & 180 & $13-15$ \\
Norsk hydro cell & 1978 & $350-400$ & $12-14$ \\
Alcan (multipolar) & 1982 & 100 & 10 \\
(Osaka Ti, Japan) & 1983 & 50 & 10 \\
Ishizuka cell & & & \\
\hline (Showa Ti, Japan) & & & \\
\hline
\end{tabular}

Table 5. Major improvements in titanium sponge production.

\begin{tabular}{lcc}
\hline Item & $\begin{array}{c}\text { Conventional } \\
\text { process }\end{array}$ & $\begin{array}{c}\text { Combined } \\
\text { process }\end{array}$ \\
\hline Ti recovery (\%) & 91 & 98 \\
Mg recovery (\%) & 92 & 99 \\
$\mathrm{Cl}_{2}$ recovery (\%) & 75 & 93 \\
Power consumption: & 37,000 & 17,000 \\
$\quad$ Titanium sponge (kWh/t) & 18,000 & 10,000 \\
$\quad$ Magnesium (kWh/t) & & \\
(Consumption only for electrolysis) & & \\
\hline
\end{tabular}

Company, Japan, are brought out. It can be seen from the table that the overall recovery values in respect of titanium, magnesium and chlorine have reached very high levels with the advent of the combined process technology and the multipolar cell. A sharp decrease in power consumption has also been registered. Further improvements if any in the Kroll process can therefore be of only marginal value. The Kroll process as currently practised is hence expected to remain as the principal route for titanium extraction for many more years to come.

\section{Technology development at DMRL}

Titanium is a metal of special significance to India for more than one reason. Quite a few of the largest and richest deposits of the mineral ilmenite $\left(\mathrm{FeOTiO}_{2}\right)$ are located in India all along the coasts of Orissa, Tamil Nadu, Kerala, Maharashtra and Andhra Pradesh. The Indian ilmenite reserves amount to as much as $30 \%$ of world ilmenite reserves, thus placing India right on top of the world list (table 6). By exploiting this vast potential the country can drastically reduce its dependence on nickel which unfortunately is conspicuous by its absence in this subcontinent. Added to this India produces only around $50 \%$ of its copper requirement, the balance being met by imports. By judicious use of titanium after a careful assessment of its life-cycle costs it should be possible to curtail the import of nickel and copper since titanium can substitute for many nickel-based alloys and cupro-nickels in several industrial applications. 
Table 6. World ilmenite resources in 1989 (000t $\mathrm{TiO}_{2}$ content).

\begin{tabular}{lc}
\hline Country & Reserves \\
\hline India & 73,000 \\
South Africa & 36,000 \\
Norway & 32,000 \\
China & 30,000 \\
North America & 27,000 \\
Australia & 24,000 \\
Canada & 7800 \\
USSR & 5900 \\
Sri Lanka & 3600 \\
\hline Total & 239,300 \\
\hline India's share (\%) & 30.5 \\
\hline
\end{tabular}

Encouraged by earlier results obtained at BARC/NFC on laboratory/pilot plant scale investigations (Ahluwalia et al 1973; Kulkarni et al 1980), a Technology Development Centre was established at the Defence Metallurgical Research Laboratory (DMRL) for the development of the Kroll process technology for titanium sponge in industrial size $2000 \mathrm{~kg}$ capacity batches. In parallel R \& D work was also initiated on fused salt electrolysis of by-product magnesium chloride so as to ensure availability of both these technologies for commercial exploitation. The centres which started functioning from the year 1985 have not only optimized the process parameters but have also generated valuable engineering data in the areas of (i) titanium tetrachloride purification, (ii) magnesium reduction of titanium tetrachloride, (iii) vacuum separation of reaction mass, (iv) handling and processing of sponge and (v) fused salt electrolysis of magnesium chloride in $30 \mathrm{kA}$ modular-type monopolar cells (Subramanyam and Sridhar Rao 1986; Subramanyam et al 1990). Figure 6 shows 2T reduction assembly positioned in the furnace. Figure 7 is a photograph of the $30 \mathrm{kA}$ magnesium cell. A $2 \mathrm{~T}$ sponge cake produced in one of the batches is shown in figure 8 .

As a result of the successful completion of the above activities work has been initiated on the development of more advanced, state-of-the-art technologies in the following two critical areas:

(i) combined process technology for titanium sponge production in 4T batches, and

(ii) multipolar cell technology for magnesium production.

Detailed engineering work in respect of the above has already been completed with technical and engineering assistance from the Indira Gandhi Centre for Atomic Research, Kalpakkam, the Central Electrochemical Research Institute (CECRI), Karaikudi and MECON who have been retained as consultants to this project. A brief outline of the proposed activities is presented in the sequel.

\section{$3.14 T$ capacity combined process equipment}

The equipment proposed to be installed (figure 9) essentially consists of a $480 \mathrm{~kW}$ pit-type electrical resistance furnace, a cooling station, a set of two stainless steel 


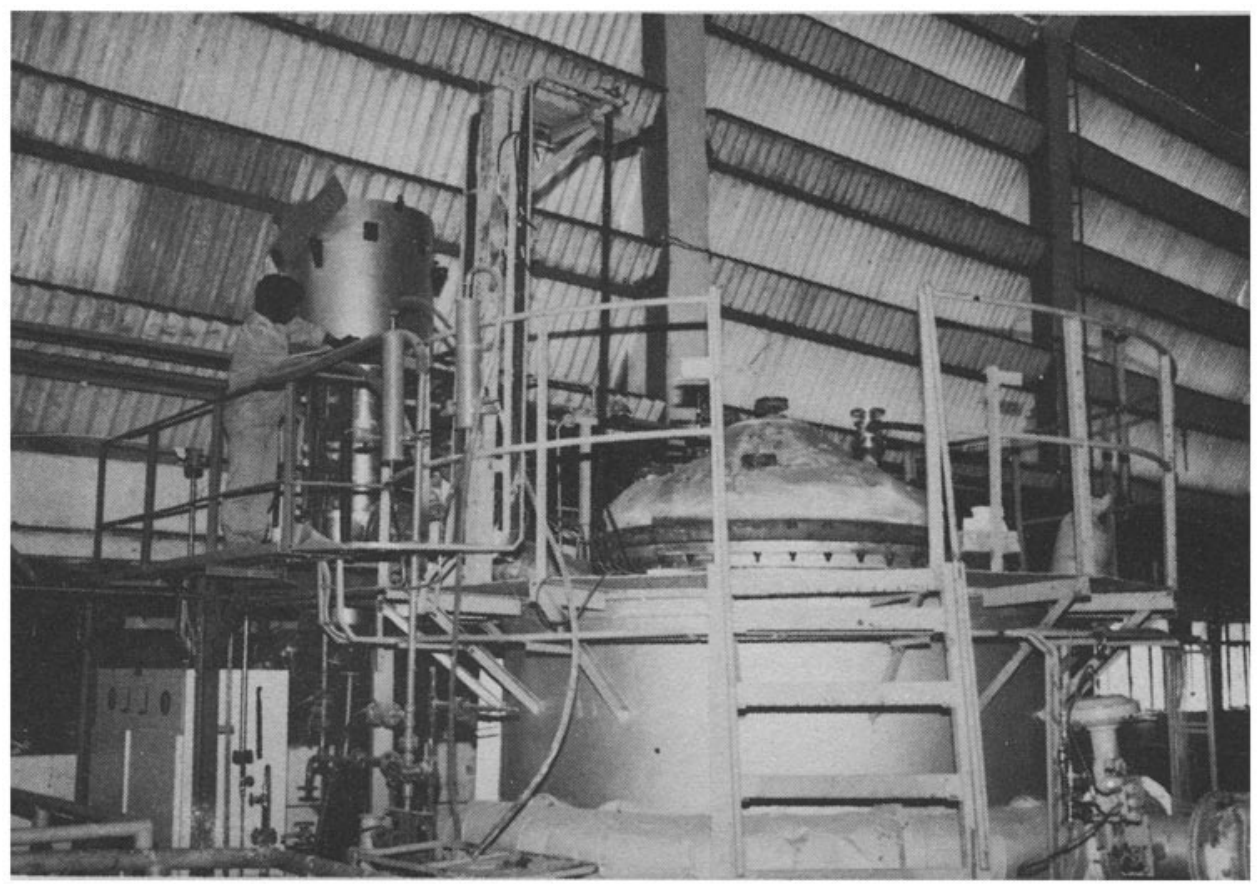

Figure 6. $2 \mathrm{~T}$ reduction assembly (DMRL).

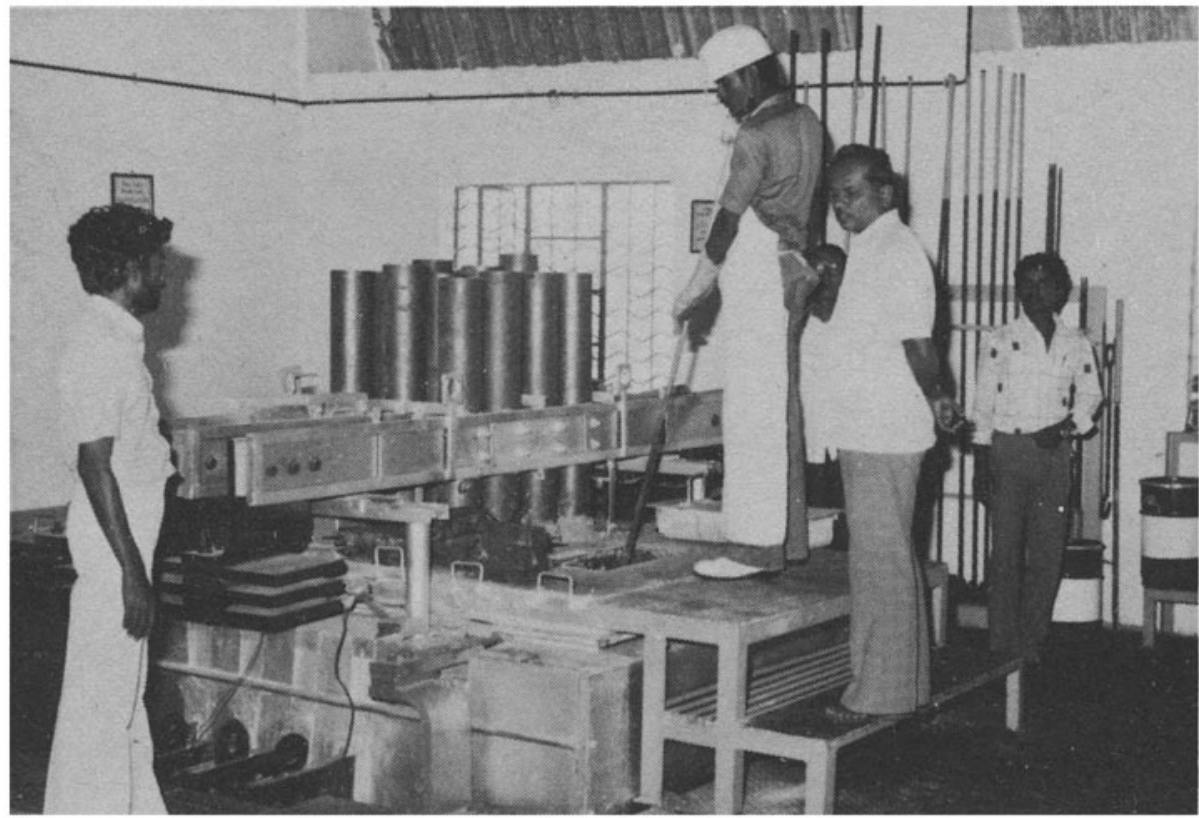

Figure 7. $30 \mathrm{kA}$ magnesium cell (DMRL).

reactors, a high-vacuum pumping system, and a vacuum ladle for receiving the tappedout by-product magnesium chloride in molten form. The design of this complex system was evolved over a period of two years of intense engineering effort during 


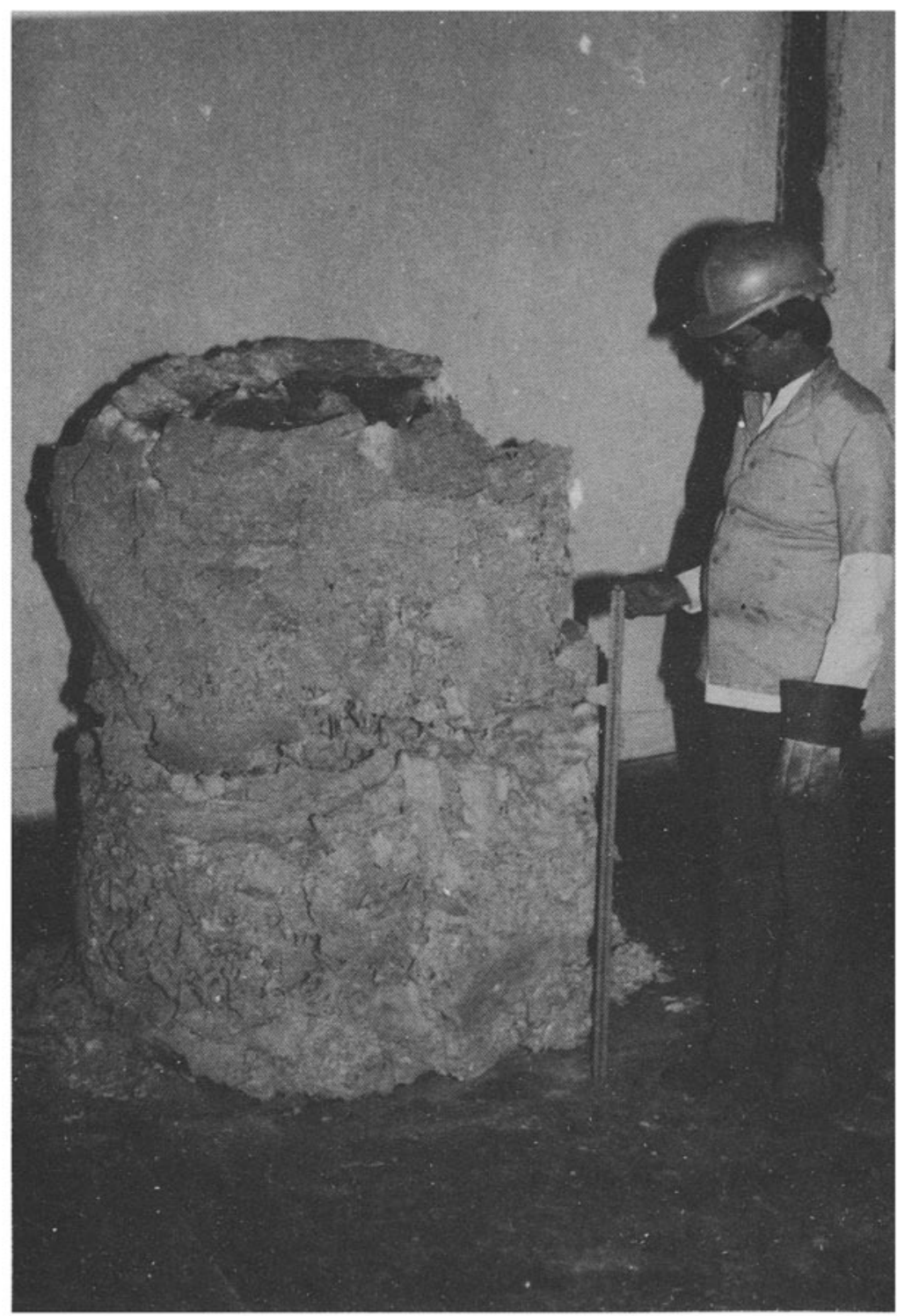

Figure 8. 2T sponge cake (DMRL).

which many alternatives were considered, evaluated and rejected for one or the other reason. Most of the components required for this system have already been ordered and some of the equipment have also been received. Figure 10 shows the specially designed furnace that has recently been erected and commissioned for this purpose.

A $500 \mathrm{~T}$ vertical press (figure 11) has been ordered for ejection of the sponge cake from the Kroll reactor at the end of the reduction-distillation process. A $630 \mathrm{~T}$ capacity hydraulic guillotine press is being procured for grading the sponge cake generally as described earlier and for primary crushing of the graded material. For subsequent communition of the different grades of sponge and for blending the final product, existing equipment and facilities will be utilized. 


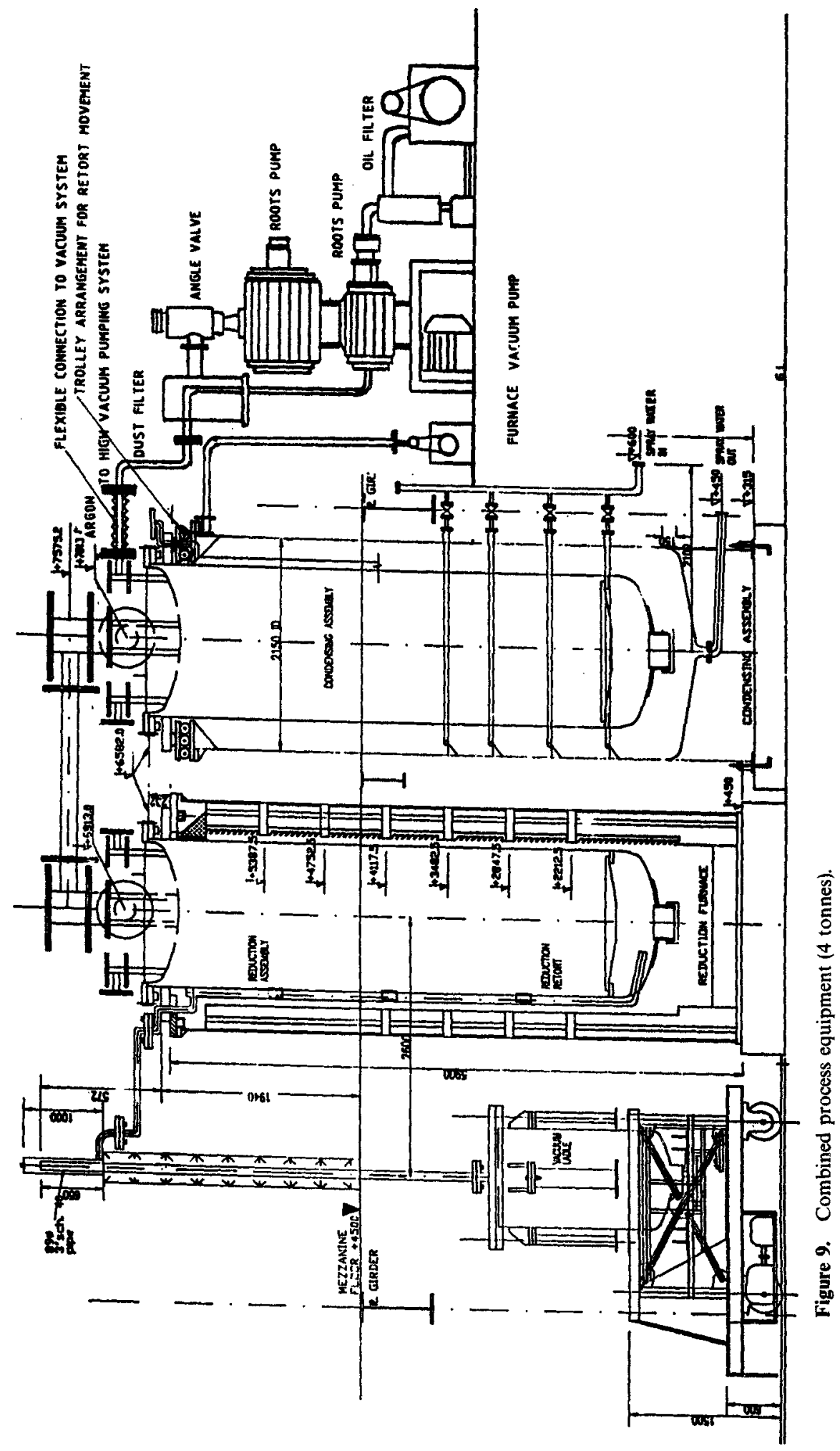




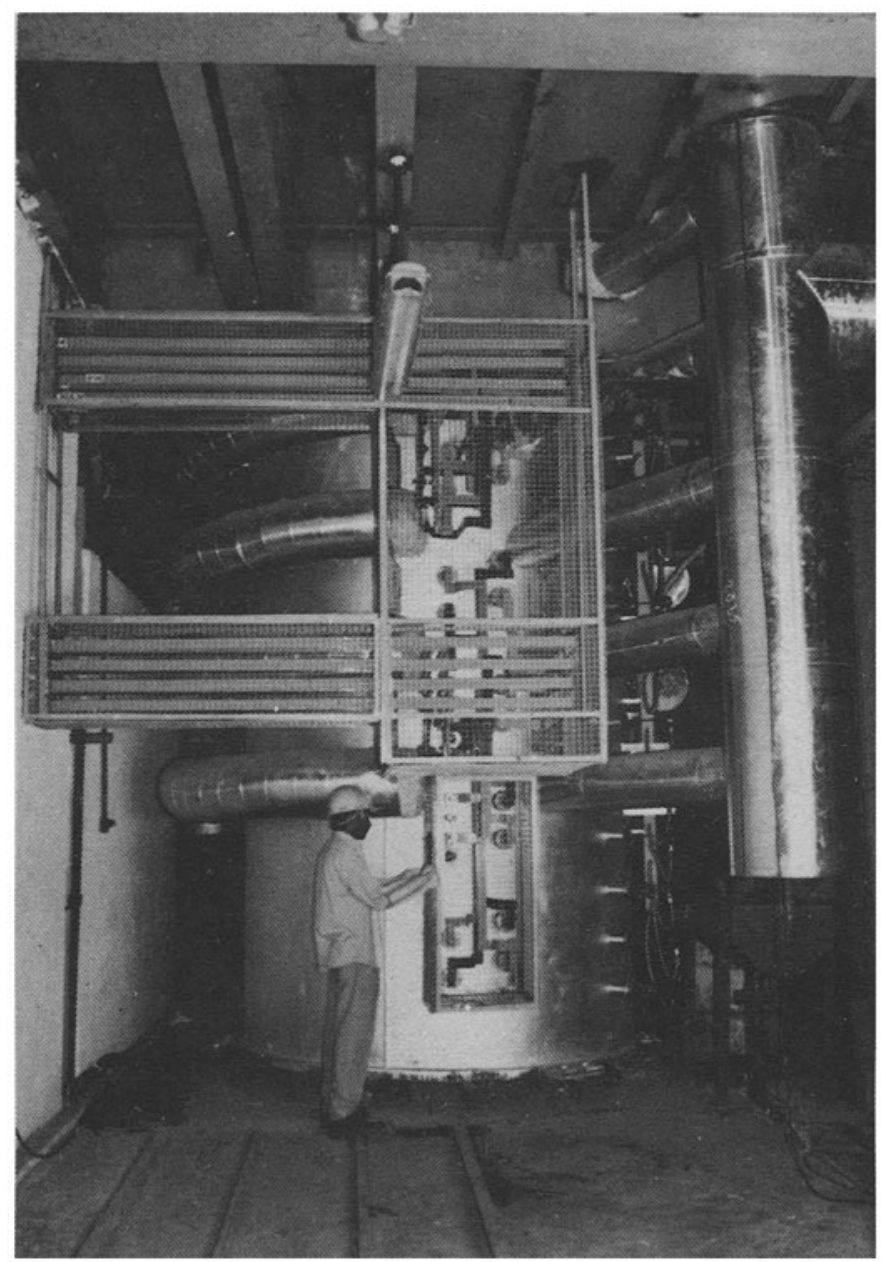

Figure 10. 4T combined unit furnance (DMRL).

\subsection{Multipolar cell for magnesium}

Based on experience gained in the operation of the $30 \mathrm{kA}$ modular type cell and the lab-scale experiments conducted by CECRI, Karaikudi, on multipolar cell, a $14 \mathrm{kA}$, $22.2 \mathrm{~V}$ multipolar cell with four modules of $3.5 \mathrm{kA}$ capacity (figure 12) has been designed. Each of the $3.5 \mathrm{kA}$ modules will have five intermediate bipoles and the cell will have a daily output of $625 \mathrm{~kg}$ of magnesium metal. Extensive heat transfer calculations have been made and suitable refractories with desired thermal conductivity have been selected. A facility for premelting of solid anhydrous magnesium chloride is being designed to enable molten feed operation of the cell. Existing facilities in respect of chlorine handling and disposal will be utilized for this new multipolar cell under construction. From the progress achieved so far on this project, it is expected that by December 1993 production trials would commence both in respect of titanium sponge production in $4 \mathrm{~T}$ batches adopting the state-of-the-art combined process technology route and magnesium production by the fused salt electrolytic route in $14 \mathrm{kA}$ multipolar cells. 


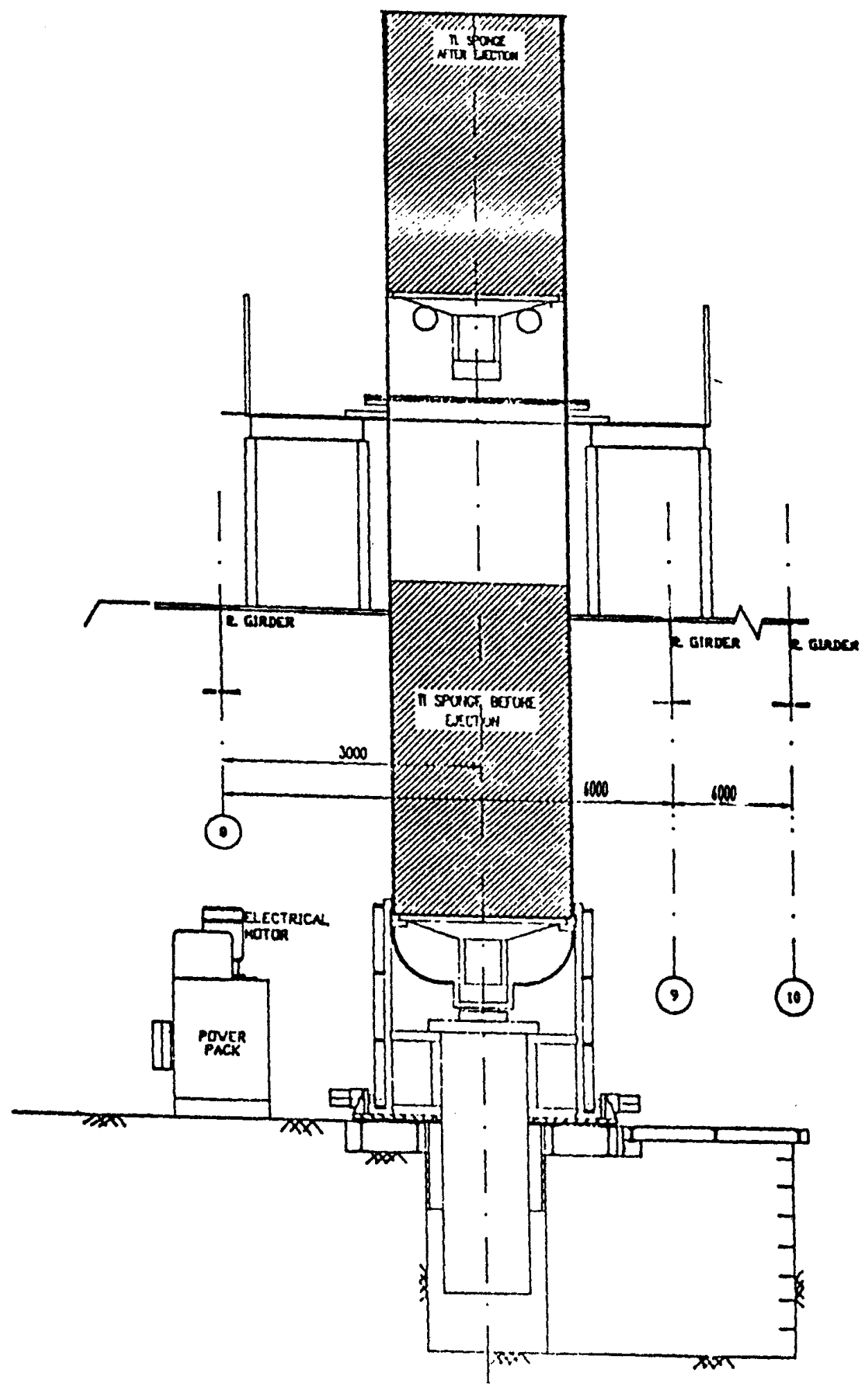

Figure 11. 500 tonnes vertical ejection press. 


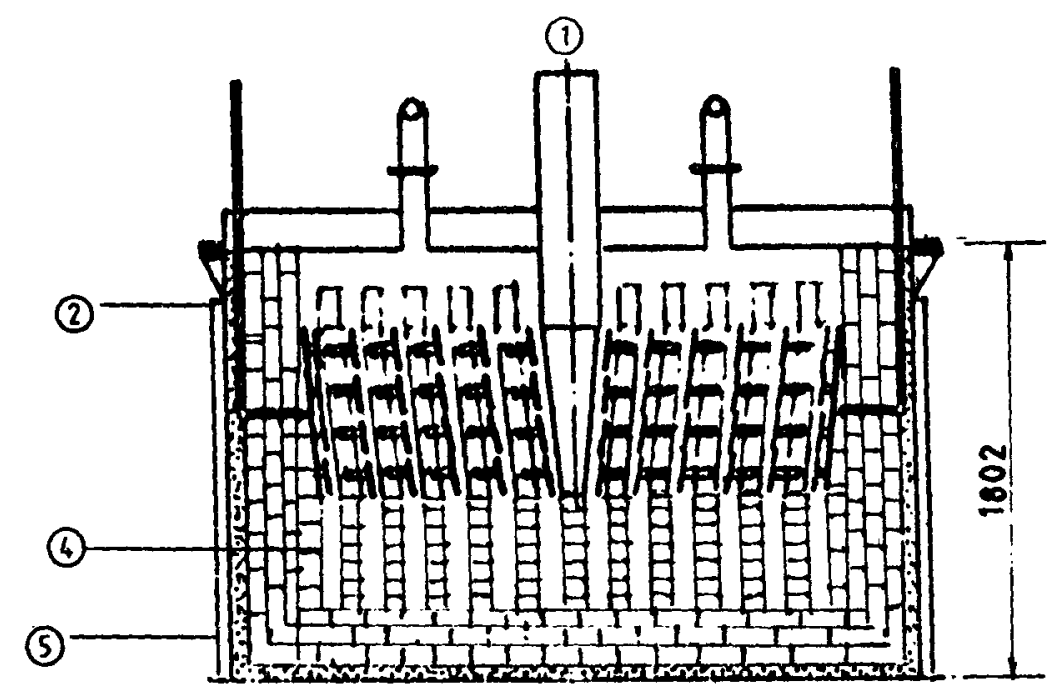

(1) GRAPHITE ANODES (2 Nos)

(2) GRAPHITE/STEEL BIPOLES ( 4 × 5 Nos)

(3) STEEL CATHODES (4 Nos)

(4) REFRACTORY LINING

(5) STEEL SHELL

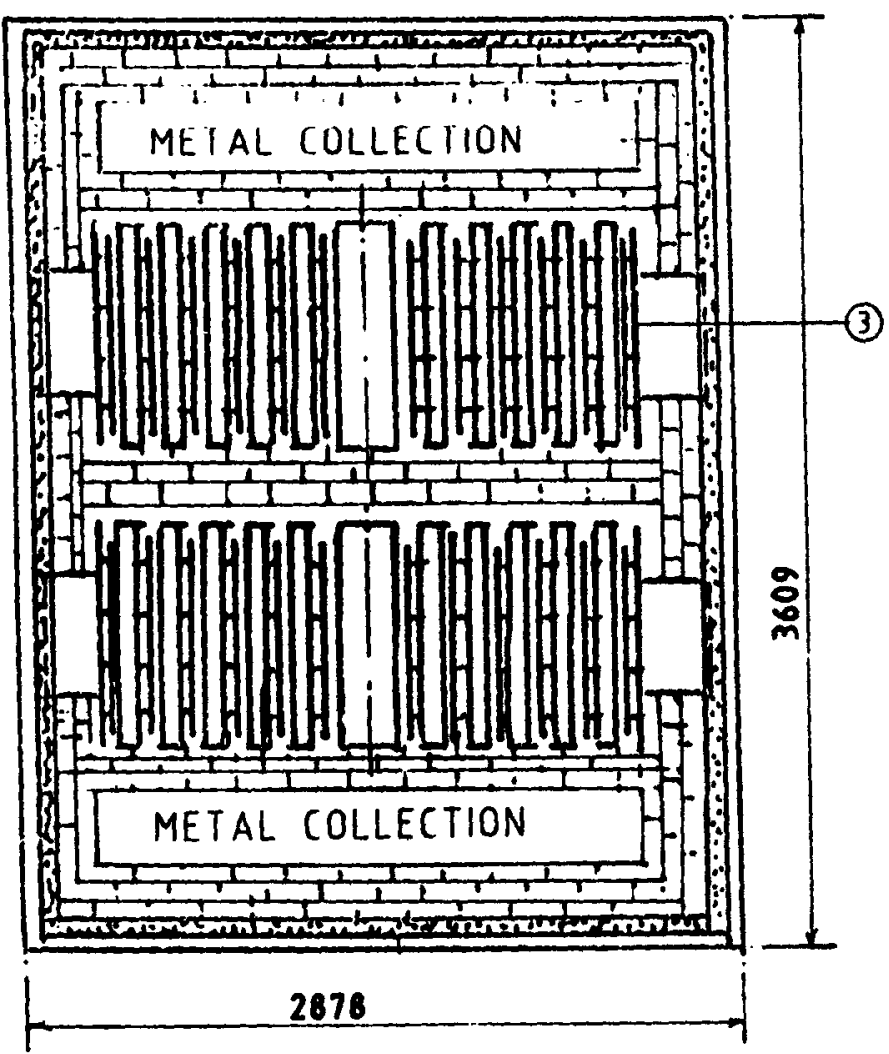

SALIENT FEATURES:

1. $14 \mathrm{kA}, 22.2 \mathrm{~V}$ MULTIPOLAR CELL WITH FOUR $3.5 \mathrm{kA}$ MODULES

2. EACH $3.5 \mathrm{kA}$ MODULE WITH 5 BIPOLES

3. METAL OUTPUT-ABOUT $625 \mathrm{~kg} / D A Y$

Figure 12. Schematic diagram of multipolar cell now proposed to be developed at DMRL. 


\section{1000 TPY integrated titanium sponge plant}

A proposal for the establishment of a 1000 TPY capacity titanium sponge plant along with a magnesium plant of 1200 TPY capacity has recently been approved by the government. This plant will be established at Palayakayal village near Tuticorin in Tamil Nadu along with a zirconium sponge plant of 300 TPY capacity. The technologies being developed at DMRL, namely the combined process for titanium sponge production in $4 \mathrm{~T}$ batches and the multipolar cell for magnesium production, will be utilized in the Palayakayal project. These facilities are likely to go into production in about four years from now.

\section{Acknowledgements}

The author wishes to place on record, with deep sense of gratitude, the financial help and support being provided by the Department of Atomic Energy but for which the large-scale developmental programmes in respect of titanium and magnesium which are currently under way at DMRL would not have become possible. The author also wishes to acknowledge the help, support and guidance being received from DMRL and DRDO in the execution of these programmes.

\section{References}

Ahluwalia H S et al 1973 BARC Report No. 683, Bombay

Aleksandrovskii S V et al 1979 Tsueatn Met. (in Russian) 49

Cameron A M, Hatten A V and Aurich V G 1987 Magnesium technology proceeding of the London conference, (Brookfield: USA: The Institute of Metals, N. American Publications Centre) Vol. 1, p. 11

Ishizuka H 1987 US Patent No. 4, 647, 355

Kroll W J 1940 Trans. Electrochem. Soc. 7835

Kulkarni A P et al 1980 Titanium science and technology (eds) H Kimura and O Izuni (Warrendale: Met. Soc. of AIME)

Kulkov A D et al 1992 Sixth World conf, on titanium, San Diego, California, USA

Petersen N H 1990 Light Metals Age 4812

Sandler R A and Zakhenvich A A 1980 Izv. Vuz Tsveatn Met. (in Russian) 614

Sivilotti O G 1984 Light Metals Age 4216

Sivilotti O G 1985 US Patent No. 4, 514, 269

Sivilotti O G 1990 US Patent No. 4, 960, 501

Subramanyam R B and Sridhar Rao Ch 1986 Def. Sci. J. 36105

Subramanyam R B et al 1990 High Temp. Mater. Process. 9195

Toshio N 1985 Titanium science and technology (eds) G Lutjerins, U Zwicker and W Bunk Vol. 1, p. 5

Toshio N 1988a J. Metals 4012

Toshio N 1988b AIME Annual Meeting, Phoenix, p. 759

Wang Ke and Ma H 1989 in W-Ti-Sb 88, Proc. of the first int. conf. on the metallurgy and materials science of tungsten, titanium rare earths and antimony (ed.) Fu Chongyue (Beijing: Pergamon - ENPIEC Joint Venture) Vol. 1, pp. 299-305

Winter C H Jr 1956 US Patent 2, 173, 760 